\title{
住宅供給の型と入居者層の対応関係より 見た新築民問借家の間題
}

\author{
正会員 宮 崎 元 夫* 正会員 福 島 寿 死** \\ 準会員 ○久松由利子***
}

住宅が現実に形をとつて表われるのは、需要者側の条 件と供給者側の条件が或る点で成立した結果である。又 各々の条件はいるいるなるのと規制されている。最近民

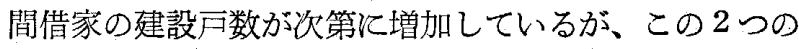
条件の対応はどのような所で成立し、今後どのよう飞発 展して行くかが問題となる。 31 年と 32 年と行なつた 2 回の調查より以上の問題を借家人側から分析することに する。第 1 次調查は建設戸数の多い大田区、新宿区、建 設戸数も少なく地域的性格も異なる台東区、江東区及び このいずれとる属さない北区の 540 件とつき行なわれ、 第 2 次調查に於ては、このうち大田区、新宿区、北区の 3 区につき 149 件行なわれた。

\section{I 住宅の型と入居者屈の対応関係}

住宅が供給される場合、需要者侧の持つ条件と供給者 側の持つ条件が働く。これがぞのようなるので、何に規 制されて変化したかを日本の住宅事情の分析から考党て 行くことにする。

○住宅專情の分析一一持家化の進行と借家一

戦前都市に於ては住宅は注とんぞ借家であつた。入居 者は比輍的土地㳔対して定着度のうすいるのがかなりウ 広く存在していた。又家主は零細な小商人、金利生活者 であつて、いろいろな閭題をともないながらも戦後供給 されたるのに比較すれば一般的に上質であり、供給量も かなりあつたと言光る。

昭和の中頃より日本経済は軍事経済に再編成され、次 第に貢金が低下すると、この項金政策の一環として地代 家貢統制が行なわれ、その結果家質の支払能力は低下し た。又これと加兄て資材統制も行なわれた結果、借家の 供給は次第に少なくなつて来た。このような時、戦災、 引揚などで多数の需要者が表われた事は、支払能力と経 営に見合う家賃との差額の問題、及びそのため供給が減 少しているという問題を一首激化させた。そして家賃統 制の継続はい上い上借家供給を減少させ、大多数の需要 者は既存住宅にわりこみ同居をしなければならなから た。しかし一応経済も安定のきざしを見せると、悪質の 住居にたえかるて、生計費に大きな歪を来たしながら持 家層に転化して行く風が表われはじめる。彼等は宅地取 得のため次第に郊外へ伸びて行き，又新たな問題をつく

* 建設省建築研究所員 **住宅金融公車職員 *** 東大大学院学生
りはじめている。この持家化の傾向に拍車をかけたのが 金融公庫をはじめとする持家政策である。

しかしこのように供給の減少した中でも借家供給は続 いていた。新築借家について見ると、第 1 表に見られる ように戦後 32 年迄の間にかなり建てられ、一時減少し ているが刃 27 年から次第に增加して来ている。これら はぞのようにして供給され、入居者はどのようなものか を見ることとする。

第 1 表 供給型別住宅着工灭数及比率（東京都）

\begin{tabular}{|c|c|c|c|c|c|c|c|c|}
\hline & $\mathrm{S} 20 \sim 23$ & $\mathrm{~S} 25$ & S26 & S 27 & $\mathrm{~S} 28$ & $\mathrm{~S} 29$ & S 30 & S31 \\
\hline 持 & $\begin{array}{r}220,654 \\
(74.0)\end{array}$ & $\begin{array}{c}65,715 \\
(93.4)\end{array}$ & \begin{tabular}{|c|}
36,564 \\
$(92.7)$
\end{tabular} & $\left|\begin{array}{|c|}44,222 \\
(34.0)\end{array}\right|$ & $\left|\begin{array}{l}44,272 \\
(80.8)\end{array}\right|$ & $\left|\begin{array}{|}45,412 \\
(76.0)\end{array}\right|$ & $\left|\begin{array}{|l}32,003 \\
(63.9)\end{array}\right|$ & $\begin{array}{l}35,648 \\
(58.7)\end{array}$ \\
\hline 家 & $\begin{array}{r}53,054 \\
(19.6)\end{array}$ & $\begin{array}{l}\mid 2,274 \\
(3.2)\end{array}$ & \begin{tabular}{|l|}
1,178 \\
$(3.0)$
\end{tabular} & $\left|\begin{array}{l}6,733 \\
(12.6)\end{array}\right|$ & $\left|\begin{array}{r}7,549 \\
(13.7)\end{array}\right|$ & $\mid \begin{array}{l}\mid 10,239 \\
(17.1)\end{array}$ & $\left|\begin{array}{l}\mid 13,603 \\
\mid(27.1)\end{array}\right|$ & 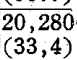 \\
\hline 給与住宅 & $\begin{array}{r}17,359 \\
(6.4)\end{array}$ & $\begin{array}{l}2,159 \\
(2.9)\end{array}$ & $\begin{array}{l}1,409 \\
(3.6)\end{array}$ & \begin{tabular}{|l|}
1,750 \\
$(3,3)$
\end{tabular} \mid & $\left|\begin{array}{l}1,965 \\
(3.6)\end{array}\right|$ & $\mid \begin{array}{l}3,174 \\
(5.3)\end{array}$ & $\begin{array}{l}2,981 \\
\mid 6.0)\end{array} \mid$ & $\begin{array}{l}2,093 \\
(3.4)\end{array}$ \\
\hline その他 & 二 & $\begin{array}{r}339 \\
(0.5) \\
\end{array}$ & $\begin{array}{r}248 \\
(0.6)\end{array}$ & $\begin{array}{r}75 \\
(0.1)\end{array}$ & $\begin{array}{l}1,017 \\
(1.9)\end{array}$ & $\left|\begin{array}{l}1,034 \\
(1.7)\end{array}\right|$ & \begin{tabular}{|l|}
1,608 \\
$(3.1)$
\end{tabular} \mid & $\begin{array}{l}2,791 \\
(4.6)\end{array}$ \\
\hline 計 & $\begin{array}{r}271,067 \\
(100)\end{array}$ & $\begin{array}{r}70,487 \\
(100)\end{array}$ & $\begin{array}{r}39,399 \\
(100)\end{array}$ & $\mid \begin{array}{r}52,780 \\
(100)\end{array}$ & $\left|\begin{array}{r}54,803 \\
(100)\end{array}\right|$ & $\left|\begin{array}{r}59,859 \\
(100)\end{array}\right|$ & $\left.\mid \begin{array}{r}50,159 \\
(100)\end{array}\right]$ & $\begin{array}{c}60,812 \\
(100)\end{array}$ \\
\hline
\end{tabular}

23 年迄に建てられた借家 53,054 戸のうち約18,000戸 は都営住宅であり、残りは症とんどヤミマーケットでめ ると言われている。公営住宅は、家梖支払能力の低下が. 量的飞大きく問題となつた結果、政府がとの解決江建設 費補助という形で乗りださなければならなくなつたるの で、従つて入居風は持家首となり得ない低額所得者が対 象となつた。公営住宅の供給は需要者数に対して非常に 少ないので、これに入居出来ないるのは既存住宅にわり こみ同居などの形で居住を続けざるを得なかつた。この 当時は戦前の家主凰は生計費にあてるため借家を売却し たり又は統制家賃や過重な租税負担のため売却したりし て没落して行き、彼等からの供給は断たれていた。この 時期に多く建設されたヤミマーケットの供給者は当然戦 前の家主層とは性格を異にしていたと考党られる。この 供給者は駅前やさかり場の地主で、戦後急激に盛んにな つた商品経済に寄生して表われたものと考光られる。及 借家人側としては次の条件があつたと考光られる。商業 は戦時中統制経済のもとでは圧迫されていたのが急激に 開放されたため、戦時中は他の仕事についていたるのが 復帰した。失業者の中から商人になるるのるあつた。又 戦炎その他で商店を失つた商人るあつた。これらの人々 は商売をはじめるためにはすず場を得る事が先決問題で あつた。又経済の見通しも不たしかで、持家を建設する 
㘪での資金は持つていなからたと思われる。しかしこの 時期の商業主 1 人当所得は勤労者のそれの約 5 倍に当り ヤ乏家貢支払可能であつたと考光られる。このようとや ミマーケットの供給及び需要はかなり特殊な性格を括び て行なわれたと考劣られる。

次に 27 年以降々供給量増加の傾向の見える民間借家 （約 95\% が尃用住宅）を見ると、その家主層は戦前と ほぼ同じ性格を示し零細な家主で、自己の宅地の中に間 貸し的アパートを建てて供給している。これて表われる 惜家人は新世帯がその主なものである。（II以下でくわ しく述べる事とする。

以上述べた住宅事情の変化から、借家供給を規定する 要素は次のようなものであると考えられる。

○現実行なわれる借家供給を規定する要素

住宅需要が発生するのは結婚により新世嘗が発生した 場合、世帯が移動した場合、災害、立退要求气の他で住 宅を失なつた場合であるが、この他沉も潜在的な需要風 は現住居に満足しない場合表われる。この住宅需要者の める首に対応して現実飞借家という形が表われているが これを規定しているるのとして以下のことが考えられ る。

(1) 借家人層はどのようなるのか。(需要者側の件)

* 一般的飞借家人層となるものはその職業上安定性が 低く、又比較的低所得者であると考学られている。

* 世带成長の初期の段階に於ては借家人首となる。こ とに戦後の状況から考皇ると、初期には借家に入居 てても、成長するにとるなつて持家層となつて行く 傾向が強く表われている。

* 経済的見通しがはつきりしない場合は借家人首にな る。ヤ之マーケットの場合。

* 供給の量及び質の変化により借家人層は変る。 戦前のように多量飞供給される場合は借家人風は币 が広かつたが戦後は量的に少なくなり借家人層の币 はせまくなる。文供給される住居の質に満足出来な

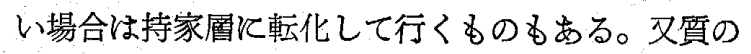
違いにより対応する借家人層は異なつて来る。

（2）供給はどのように変化するか（供給者側の条件）

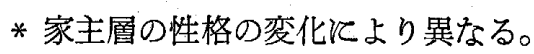
戦後の家主層の没落により住宅供給は減少した。

* 家主として異なつた性格を持つるのの登場による変 化。

ヤミマーケット、公営住宅、公団住宅、高級アパー 卜の供給者は, 寄生地主、政府 (公営住宅と公団住 宅供給はその性格を異にする) 大企業であるが、こ れらの住宅は質的量的に異なつている。

* 現在行なわれている借家関係认内在する問題が、供 給する住宅の量と筫倅化を与える。

相互に関連する借家人層の変化と、供給の変化で借家
供給は次第に発展して行く。そしてこの要素はすべて日 本経済の動行に基本的には支配されている。最近民間借 家建設が伸びているが、これにはどのような層が入居し、 今後の発展の方向はどのようなるのであるかを、借家人 側から分析することにする。

\section{II 新筑民間借家入居層はどのようなものか}

新築民間借家は品川、中野、太田、新宿の上うな交通 の便の良い住宅地多く貄てられているが、アパート形 式が多く見られ、室構成も一室のるのが非常に多い。この ような借家が多量に供給されるようとなつたのは、供給 者側の条件と、需要者側の条件がこの点で成立した事を 示しているが、この入居者首がどのようなるのであり、 又どのよろな問題を内在的に持つているかを知ることは 今後の需要と供給の対応飞影響を与兄るるのである。そ の点から 1. 入居者はどのような階風嘱するか、( の指標として職業と収入をとりあげる。）2. 世帯の生長 段階はどのようなるのか、3. 供給される他の借家の入 居層とぞのように違うか、を問題としてとりあげIIIで内 在している問題について述べる事にする。

○入居者はどのような階首に属するか。

新築民間借家入居者情給生活者が最も多い。そのう ち高級サラリーマン(部長、課長級)は1例す見られず、 瓜とんど全てが下級サラリーマン（役付でないすの、平 職員)である。次多いのが筋肉学衝者で、そのうち工 員がかなり多い。

これを入居している住戸の型（アパート、長屋、一户 建）別に見ると幾分違いが出て来る。いずれの場合る俸 給生活者が最も多数をしめるが、長屋、一戸建、アパー トの順にとの割合は次第に高くなつて行く。長屋建に於 てこの他見られるのは工員、店主工場主(小規模なもの) である。

通勤地別に見ると中央区、千代田区《勤めるサラリー マンがかなり多い。この他同じ区内に勤め先を持つるの もかなり見られる。大田区に於てはその傾向がはつきり 乙て挌り区内の工場酒勤しているすのが多い。

次に入居者の実収入はどのような分布を示しているか を、30 年 12 月より 31 年 1 月にかけて行なわれた第 1 次 調査より見ると 20,000 円前後に集中して表われる。 20,000 円が約 $1 / 3$ 強、次化 15,000 円、10,000 円の順炡 なつている。一方昭和 31 年 1 月現在の東京都全世帯の 実収入を家計調查(総理府統計局)より見ると、28,000円 〜32,000円が最も多く、これとついで20,000 28,000円 の収入のものが見られる。このことから新筑民間貸家入 居層は東京都の中でる低額所得者であることが知られ る。

○ 世帯の生長段階

家族構成は大体単純家族で、世带人員は 2 人乃至 3 人 である。世帯主年令より見ると 30 才 34 が多く、入居 
動機としては、独立、結婚、家族数の増加、及び業務上 の都合、前住居の居住条件を理由としてあげている。従 つて、主なる入居層は戦後発生した新世帯であることが 判明する。

これをアパートと一般借家に別けてみると、アパート の世带主年令は若く25 34才が最も多く、入居動機も結 婚によるものが多い点から、新しく発生した世帯で、世 带の成長の最初の段階にあり、住宅市場飞初的て登上し たものが大部分であることが解る。一般借家はこれより 年令子多く、入居同機子家族数増加、前住居の条件、它 理由としている点から、前住居が満足を与えない結果再 び市場に表われ現住居を取得したものと考えられる。

○供給される他の借家入居首との違い。

借家市場に表われた需要者效して、新築民間借家の 他飞公営、公団住宅、建築年代の古い借家、いわゆる高 級アパートなどがあるが、このうち量的とる多く、これ 加ら先る供給されると予想される公営、公団住宅入居者 層との違いを考党てみることとする。

公営住宅入居申込希望世帯 (昭和 30 年住宅事情調查 市部計）と比較すると、事務学働者が多く月収は14,000 円にそのピークが見られ、大体の傾向としては新築民間 借家入居層のうち比較的低収入者が入居を希望するもの と考克られる。

今後供給の伸びて行く傾向の見られる公団住宅の入居 申込者と比較すると（儥貸住宅申込者実態調查）月収 25,000 円 30,000 円の世帯が57\% をしめているが、 新築民間借家の場合は 20,000 円以下の世帯が $73 \%$ を しめ、月収からはかなりの相違の見られる事が判明する。 次江民間借家入居首も世帯が生長すれ法公団住宅入居層 となり得るのではないかと言う問題が出て来るが、公団 住宅入居者の世帯人員のうち最も多いものは 2 人である ことから、新しく形成される新世帯が主要なる圓である と思われ、かなり異なつた層であると思われる。しかし 世带人数の平均をとると 3.3 人を示し、新築民間借家入 居者中現在の質の悪い居住条件を打開するため努力して いると答光たるのが約 $1 / 4$ あ点から考皇て小数のものは 公団住宅入居層となり得ると考えられる。

新築民間借家入居層怯公営公団住宅入居層にくらべて その収入の点からは币広く存在している。このうちごく 小部分は公団住宅入居層之ほが同じ性格を示すと思わ水 る。又低収入者である一部分は公営住宅入居希望層と同 じ性格を示すが、この中間のものが最も多いのが特色 である。

\section{III 現在の借家と借家人の対応関係に内在する問題}

○定住性が低いということ

このように新築民間借家に入居したものはどのような 状態でどのような動きを示すかを見ると次のことが判明 する。これらの借家は 26 年より 29 年に新築されたる
のであるが借家人の変更が非常に多く、第 2 表に見られ るように約半数ある。これを住戸の型別に別けてみると その共用化の進えだものほど、言いか党るなら住戸の独 立性が低くなるほ ぞ借家人の定住 性はなくなると言え る。

第 2 表 借家人の変更状態

\begin{tabular}{c|cc|c}
\hline 住戸の型 & 变つた & 変らない & 計 \\
\hline I & 3 & 8 & 11 \\
II a & 20 & 52 & 72 \\
II b & 18 & 31 & 49 \\
II c & 36 & 18 & 54 \\
II ab & 3 & 2 & 5 \\
II ac & 11 & 6 & 17 \\
II ad & 19 & 6 & 25 \\
\hline 計 & 110 & 128 & 284 \\
\hline
\end{tabular}

注

I $: 1$ 戸建 II $\mathrm{a}$ ：壁面共用(長屋建） II $\mathrm{b}$ ：出入口廊下共用(アパート)

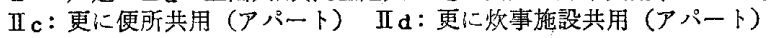

借家関係が短期間しか継続されないという事にはいる いろな理由が考兄られる。

1. 家主側が投下資金を早く回収するため借家人を変 えて一時金をとろうとする場合。

3. 借家人の職場変更による流出。

3. 借家人の住居に対する要求が満されないため流出 する場合。

1 の問題については、契約期間を定めて終了の際立退要 求をするのではないかと考えられる。契約期間を定めて いるものは半数を少し上まわり、その年数は 2 年 3 年 が多い。乙かし契約期間終了の際にどうするかという問 題に対して家主は注とんどすべてが継続すると答えて特 り契約期間は契約条件の据置期間と解され、立退要求の ためとは考光られない。又借家権が強化されている今日 では家主側の要求で流出することは少ないと考党られる

次に 2で述べた問題であるが、これら民間借家の多く 供給されている地域ね交通に便利な住宅地が多いため都

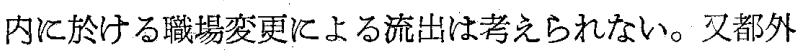
流出人口ほ少ないため 2 の問題による流出は少ないと考 えられる。

第 3 表 将来の住居に対する意識

\begin{tabular}{c|c|c|c}
\hline 借 家人の意識 & アパート & 一般借家 \\
\hline \multicolumn{1}{c|}{ 現在の借家に住む } & 158 & 141 \\
& 現在の借家に居たくない & 153 & 61 \\
\hline \multirow{2}{*}{ 内 } & 見通しがある & 37 & 13 \\
訳 & 努力している & 82 & 41 \\
& しかし見通しがない & 34 & 7 \\
\hline
\end{tabular}

次は 3 で述べた問題であるが、これをアパート居住者 の借家関係 継続に対する意識から見ると次のことが解 る。現在の借家関係を続けたくないという意志表示をし たるのが続けると答えたるのとほぼ同数めり、その半数 以上がはつきりした見通しを持つていない。（第3表） 又前述したように住戸の質の低下と共に流出度が高くな 
つているととからも考觉ると、流出の原因は現住居に対 する不満の表われと解釋される。．この問題を住居の規模 と世帯人数の問題、及び住戸の独立性の問題から以下述 ベる事にする。

(住戸の規模と世带人数)

戦前の借家と戦後供給された借家を較べて見ると、戦 前の東京に於てはその室構成が 3 室のものが最も多く、 次に 2 室のすのが見られる。戦後供給されるすのは 1 室 のものが非常に多い。

この居住形態を見ると 4.5 畳に 2 人といらケースが最 も多く、これについで 6 畳に 2 人、 7.5 疊に 3 人が見ら れる。これを 1 人当畳数を指標にとつて見るなら、2.5 畳末满のものが 2.5 畳以上のものより多く表わる。

又かりに政府の規定する狭小過密居住（居住室㽪数が 9 畳末満で 1 人当畳数が 2.5 胃末満のもの）を現在の社 会に於ける筫悪なる住居と仮定するならば、アパートル 於ては半数以上のるのがこれに該当し、借家に於ては $1 / 3$ がこれと該当する。この(第 4 表)ことは今後供給されて 行くもの之して大きな問題であると言わなければならな い。この規模の狭さが住居に対する独立した世帯の要求 を満足させない一つの点であると思われる。

第 4 表 狭小過密居住の状態

\begin{tabular}{|c|c|c|c|}
\hline & & アパート & 借 \\
\hline \multicolumn{2}{|c|}{1 人当䁌数が 2.5 帖末満のもの } & 97 & 46 \\
\hline$=95 \hbar$ & $\begin{array}{l}\text { 居住部分が } 9 \text { 帖未満のもの } \\
\text { 居住部分が } 9 \text { 站以上のもの }\end{array}$ & $\begin{array}{r}90 \\
7\end{array}$ & $\begin{array}{l}30 \\
16\end{array}$ \\
\hline \multicolumn{2}{|c|}{1 人当胃数か： 2.5 蛅以上のもの } & 71 & 45 \\
\hline このむち & $\begin{array}{l}\text { 居住部分が } 9 \text { 帖末満のもの } \\
\text { 居住部分が } 9 \text { 帖以上のもの }\end{array}$ & $\begin{array}{l}53 \\
17\end{array}$ & $\begin{array}{l}11 \\
34\end{array}$ \\
\hline
\end{tabular}

（住戸の独立性）

借家人の流出度の高いものの独立性を見ると第 2 表に 見られように $\mathbb{I}_{\mathrm{a}}$ 型が多く、出入口、廊下、便所、炊事 施設が共同のものとなつて物り、居住室のみ壁でへだて られている。このような状況のもとでは独立した世帯の 生活はかなり阻害されるものと思われ、流出の原因を形 作つていると思われる。

○家賃負担率

新築民間借家の家賃は2,500 円から 3,500 円が多く、 大体5,000円以下の所飞分布している。又一時金は20,000 円、50,000円、30,000円などかなりばらつきが見られる。 一般的に家貨は収入の $1 / 6$ と考兄られているが，新築民 間借家に於ては家貨負担率 $16 \%$ 以下のものは約 $1 / 4$ で他 は非常に高い率を示し、30\% 以上のるのをとると $1 / 4$ 強あ る。この家顀負担汶対する借家人の意識は、重いと答兄 たものが半数以上もあることからもこれらの借家恃家顀
の面からも決して適切なるのであるとはいえない。これ は貨金す兄置きと家賃統制による家貨の差額がここにし わよせられた結果と思われる。このため新築民間借家入 居者のうち高収入者のごく小部分は持家層となるため流 出すると考光られるが、他の大部分の借家人風にとつて は今後とも大きな問題であると言える。

\section{IV ま亡め}

住宅の供給のされ方は供給者側の条件と需要者側の条 件によつて異なる。又气の条件は基本的には日本経済の 動きにより支配されるが、階層（職業及び収入）世帯の 条件により異なつて来る。このような中で戦前住居の一 般的な形であつた借家が一時的に減少したが、次第にそ の供給を増して来ている。その対応関係を借家人の側か ら見ると、新世帯が非常に大きくあらわれている。しか しそれも 4 5 年のうちに出て行く。この傾向はアパー トに多く見られ、その原因は現在の借家の居住条件の悪 さである。これは規模の小さいこと、及び独立性の少な い事がその主なるものと考光られる。又持家首となつた 人々にとつては高額な家䝯がその原因であると考兄られ る。

このようとより良い住居を求めて流出して行く借家人 の動きは供給側飞働きか计次第により良質な借家が供給 されるのではないかと思われる。それは以下の理由によ る。最近までは流出する凰の一部分は持家風となり得た が、宅地難がいよい上激化される今日、その道は当然閉 ざされて行く傾向にあり、そのため借家が供給されるよ うとなると考兄られる。又借家人首が量的に増加せざる を得なくなると良質な借家を要求する動きは強く働くよ うとなる。しかしこれにはいるいるな問題がある。良質な 住居が供給されるためには当然家貨の上昇をともなう。 家貨上昇は生活の圧迫をるたらしながら、次第行なわ

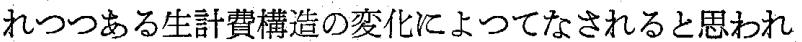
る。これは所得の増加を前提としているが、ここで問題 となることは、この家貨上昇について行けない階層が多 いことである。公団住宅入居層をとの指標にとつてみる そ、大部分がこの層に属さないことからもうかがえる。 現在の家賃負担率がすで問題となつていることから

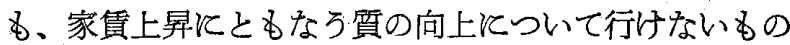
が多い事が知られる。借家と借家人の対匛の中に内在し ている問題が働いた結果、新しく住居は供給されて行く が、これらの圈にはより低い水準で住居が与兄られ、生 活に歪を残し、内在する問題を大きくしながら新しい借 家供給は進んで行くるのと思われる。このような借家を 供給する家主はどのような所から登場し、どのような条 件を持つかという面の分析は今後残された問題である。 